\title{
Competency Mapping for Effective Growth in Retails
}

\author{
Dr. Aradhna Yadav ${ }^{1 *}$ \\ ${ }^{1}$ Department of Management Studies, New Horizon College of Engineering, Bangalore \\ ${ }^{*}$ Dr. Aradhna Yadav, E-mail: yaradhna@gmail.com \\ Received: January 6, 2017 \\ Accepted: January 30, 2017 Online Published: February 7, 2017 \\ doi:10.22158/jbtp.v5n1p1 \\ URL: http://dx.doi.org/10.22158/jbtp.v5n1p1
}

\begin{abstract}
Competency mapping is a procedure through which one assess and determines one's strength as an individual operative and in some cases, as part of organization. Competency mapping helps in analyzing the blend of strengths of different workers to produce the most effective teams and highest quality work. Competency framework serves as the bedrock for all HR representatives. Identifying and providing training enables better performance management. Competency mapping is the base system for recruitments, promotions, training and Career Development, performance analysis. It also helps in analyzing the strengths and weakness of the employees. This study explains the relevance of competency mapping in a retail outlet for the purpose of Training and effective results.
\end{abstract}

\section{Keywords}

performance management, training and career development

\section{Competency Mapping-An Overview}

Employees today are the organizations biggest assets. They are responsible for the success of the organization. Organizations believe it is better to develop a core competency so that they would passes through any emergency. The success of the employees depend on their skills, level of knowledge, and ability of the employee.

Chankya's bolok Arthashastra is considered as the initial book of competency mapping. It is the ancient management book that provides excellent guidance to professionals. The book contains theories, practices, competency mapping model, suggestions, methods and techniques for effective management. According to Boyatzis (1982), "A capacity that exists in a person that leads to behavior that meets the job demand within the parameters of the organizational environment, and that, in turn brings about desired results". According to Hogg (1989), "Competencies are the characteristics of the manager that lead to the demonstration of the skills and abilities, which result in effective performance within an occupational area. Competency also embodies the capacity to transfer skills and abilities from one area to another".

Competencies help the employee's in multi-tasking. The employee skills can be improved by many other skills instead of just restricting him for only one skill. The various organizations have their own competency model. HR plays the major role in identifying and nurturing the competencies of employees. The skills, knowledge and attitude are the attributes of the competencies.

Competency mapping can be categorized into technical, managerial and behavioral. By using correct methods talents of employee's are identified, it also improves employee's engagement and retention. The study helps in understanding the strengths and weakness of employees and helping them to improve it. 


\section{The iceberg competency model}

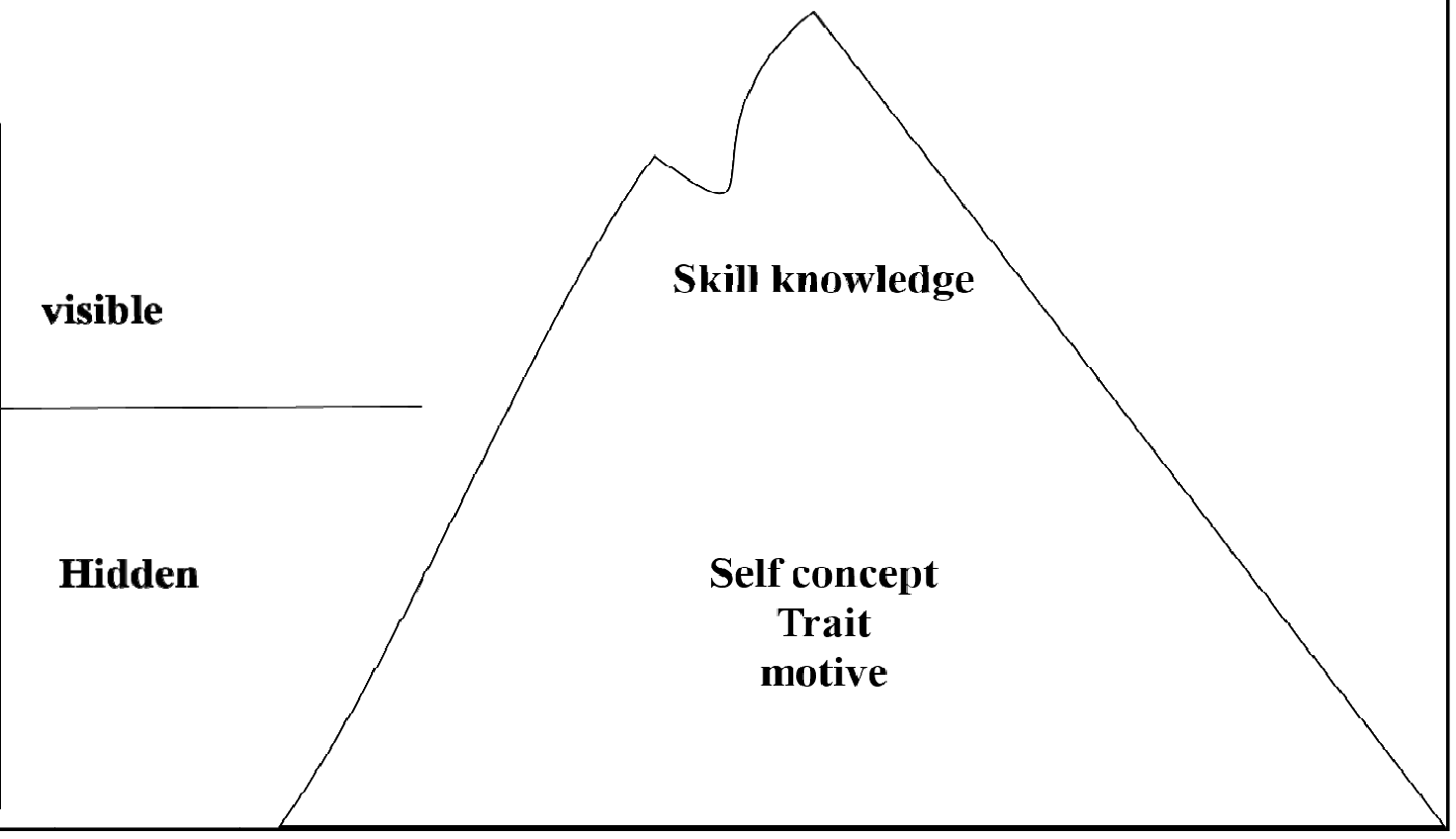

Figure 1. In Iceberg Competency Model only Skill and Knowledge is Visible Characteristic of the Humans. But Self-Concept, Trait and Motive are not Known to Others, it is Hidden

\subsection{Surface and Central Competencies}

The surface competencies are easy to identify, develop and to give effective training to improve the employee's performance and confidence. The central or core competencies are difficult to identify, train and develop. It takes lots of money and time to develop the core competencies. But many of the organizations invest in developing the core competency of the employee. 


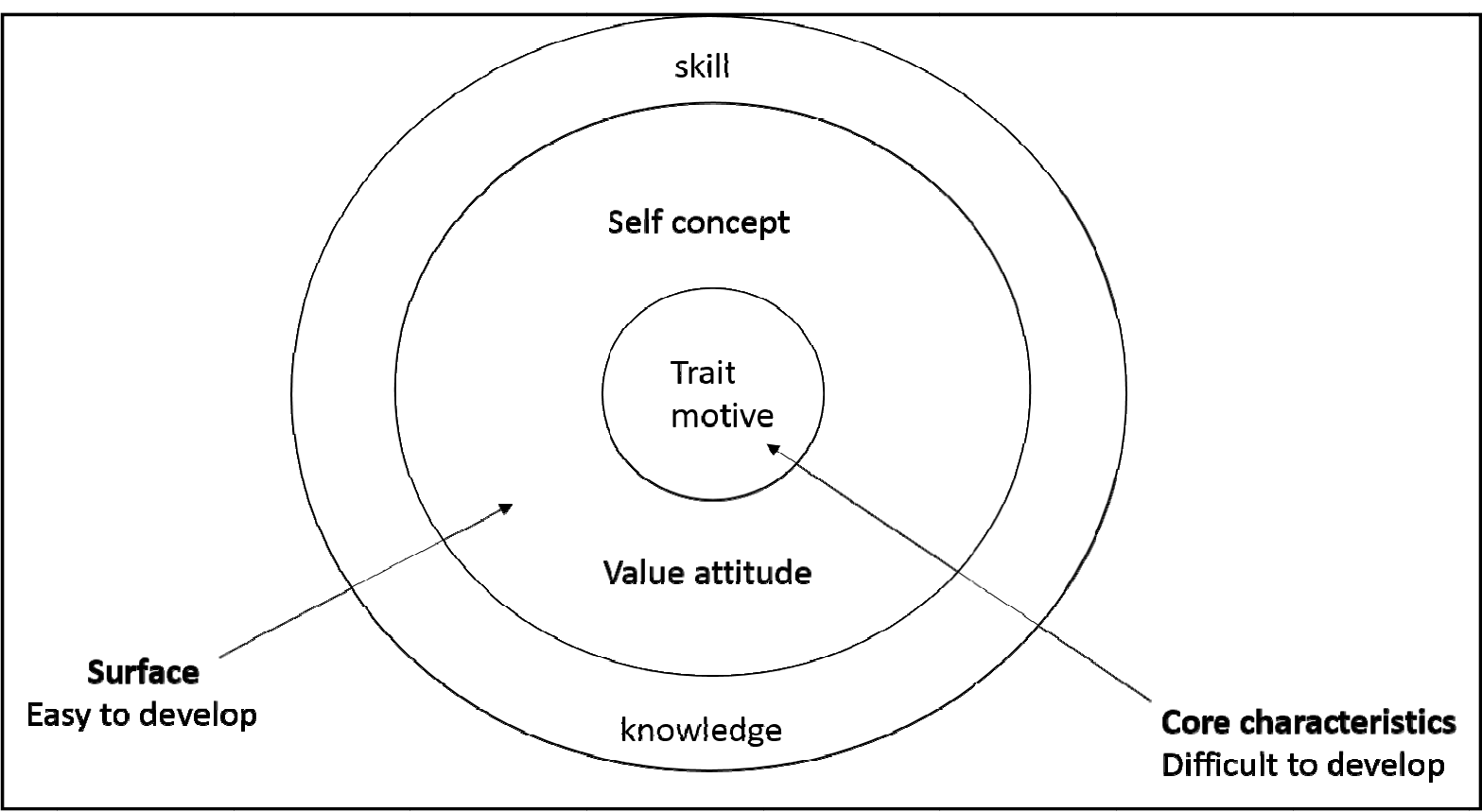

Figure 2. Surface and Core Competencies

\section{Statement of the Problem}

Problems faced by retail outlets in identifying the skills and competencies of employees and to map them effectively for Organizational effectiveness.

Competency mapping is a process which identifies an individual's strength and weakness in order to help them to better recognize themselves. Here, the competencies are mapped according to the individual's skill, ability and talent in the working condition. It leads to increased capacity by achieving a more holistic view of the accumulated competence of the entire organization. At this juncture the study has been conducted to identify the benefits of competency mapping.

\section{Review of Literature}

This study has improved the organizations capacity and has positive impact on the private manufacturing ltd. Orooj (2014), competency mapping: an HR practice enhancing the employee productivity and growth. In this research the author talks about McClelland Occupational Competency movement which was initiated by David McClelland. He describes competency in terms of knowledge, skills and attitude. Based on employee's requirement, training and development is provided to them. Explains that the capability of employees can be increased by providing career and succession planning programs. In this programs employee's skills are identified and groomed. All the HR practices like management development, performance appraisal, training and development, career development has positive and improving results with competency mapping. Yuvaraj (2011), A drive for Indian industries. Different industries have different competencies requirement for their employee's. Based on the industry the competency mapping has to be performed. The survey was conducted and comparison was made between competencies found by survey to the required competency of employee's to perform a particular job. Sawant and Avinash (2012), the employee's satisfaction level was high due to competency mapping performed in organization. If the training is increased in the organization then the competency level of the employee's also increases thus increasing the employee potential and their productivity. 


\section{Objective of the Study}

1) To identify and describe the factors which are crucial for the functioning of a particular job.

2) To understand job allocation and growth of the employee (career development).

3) To study and analyze impact of training for building competency pool in the organization.

\section{Research Methodology}

Retail outlet of Future Group (Big Bazar) has e been taken as sampling unit for the study. The study being analytical nature, 100 respondents of such outlets has been selected as sample respondents by using convenient sampling technique. Interview schedule has been used as an instrument to conduct this research. A well structured close ended interview schedule with questionnaire relating to-level of competencies of personnel, Training effectiveness, aims of competency mapping and the benefits of competency mapping have been framed to obtain primary data from the respondent group. The secondary data for the review were sourced from Journals, Article on Retail outlets in India. The study period extended for about 4 months from December 2015 to March 2016. In order to analyze the objectives of the study, statistical techniques viz., Chi square test, ANOVA have been used to test the relationship among the variables taken for study.

Big Bazaar is the consumer goods retail chain of future group Pvt Ltd. It is the leading hypermarket chain in India. Big Bazaar deals wide range of merchandise such as home furnishings, utensils, crockery, cutlery, sports goods, electronics, toys, footwear, men's and women appeals, accessories such as sunglasses, watches, handbag, luggage, fruits, vegetables and stationary products. This company has its stores all across India. This stores was the concept of Walmart USA.

Future group also has brand factory, pantaloons, central hypermarket, eZone, home town, future bazaarcom, KB's price, tasty treat, fresh \& pure and ektaa. Future group provides services like supermarkets, hypermarkets, discount stores, insurance, logistics and media. There are more than 35,000 employees working under the future group. Big bazaar successfully completes 10 year in retail industry in 2011. In 2012, big bazaar signed a multi-million dollar deal with cognizant technology solutions for the development of an IT infrastructure which consists of future group warehouses, stores, etc.

\section{Analysis}

Is skills and efficiency important for better performance? Does competency mapping help in performing better?

The view of the table makes one to understand $77 \%$ of employees have admitted that skills and efficiency is important for better performance. The $43 \%$ of employees have given maximum rating of score 4 while $7 \%$ of employees have given the least rating of score 1 .

Table 1. Crosstab

\begin{tabular}{|c|c|c|c|c|c|c|}
\hline \multicolumn{7}{|c|}{ Count } \\
\hline & \multicolumn{6}{|c|}{$\begin{array}{l}\text { rating for com } \\
\text { perform better } \\
\end{array}$} \\
\hline & 1 & 2 & 3 & 4 & 5 & \\
\hline Is skills and efficiency important for betteryes & 6 & 8 & 25 & 33 & 5 & 77 \\
\hline performance & 1 & 5 & 4 & 10 & 3 & 23 \\
\hline Total & 7 & 13 & 29 & 43 & 8 & 100 \\
\hline
\end{tabular}




\section{Hypothesis:}

$\mathrm{H}_{1}$ : Opinion on if Skills and Efficiency helps in better Performance Independent of Rating for Competency Mapping will Helps to Perform better

Table 2. Chi-Square Tests

\begin{tabular}{cccc}
\hline & Value & Df & Asymp. Sig. (2-sided) \\
\hline Pearson Chi-Square & $4.394^{\mathrm{a}}$ & 4 & .355 \\
Likelihood Ratio & 4.294 & 4 & .368 \\
Linear-by-Linear Association & .142 & 1 & .706 \\
N of Valid Cases & 100 & & \\
\hline
\end{tabular}

a. 3 cells $(30.0 \%)$ have expected count less than 5 . The minimum expected count is 1.61 .

INTERPRETATION: The chi-square test has shown that the hypothesis is accepted. Since the significant (0.355) value is less than 0.05 hypothesis is accepted. Concludes that employees have agreed that skills and efficiency is important for better performance and competency mapping will help employees to perform better.

Are for current positions allocated and based on Competency mapping by Organization, irrespective of the years of experience.

Cross tabulation of response on rating for current position years of experience has been tabulated under. From the glimpse of table $42 \%$ of staff have given rating 4 for current position and minimum rating is given as $9 \%$. 51\% of employees are fresher, while only $3 \%$ had $5-10$ years of experience.

Table 3. Crosstab

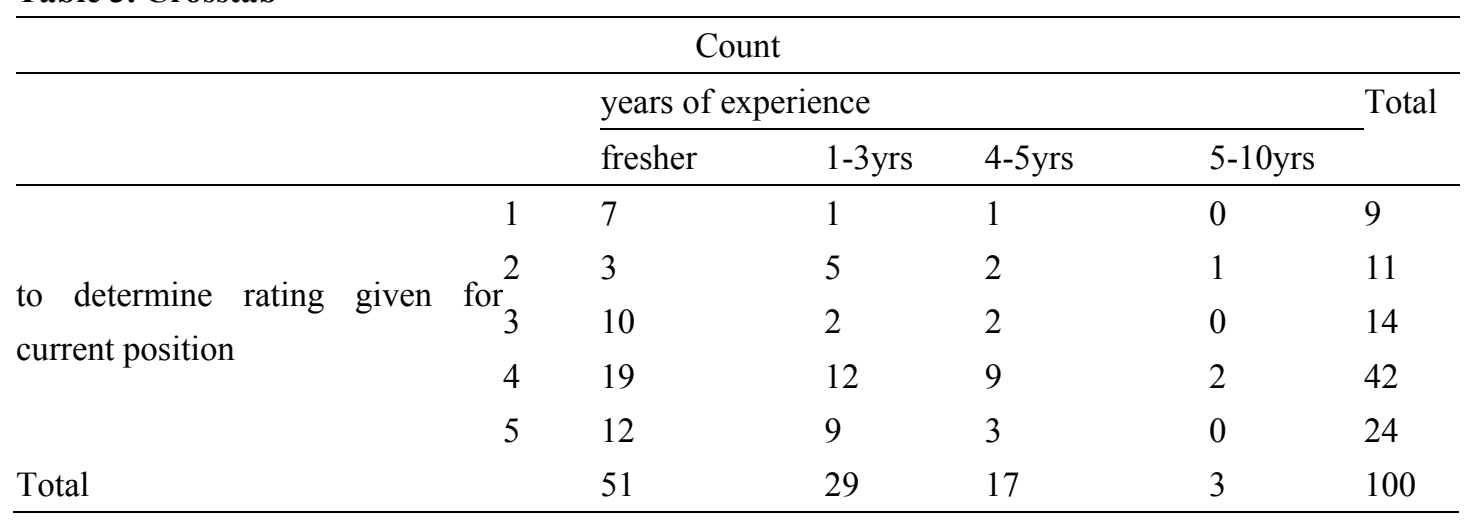

\section{Hypothesis:}

$\mathrm{H}_{2}$ : Opinion on Rating on Current Position is Independent of Years of Experience

Table 4. Chi-Square Tests

\begin{tabular}{cccc}
\hline & Value & df & Asymp. Sig. (2-sided) \\
\hline Pearson Chi-Square & $11.798^{\text {a }}$ & 12 & .462 \\
Likelihood Ratio & 12.982 & 12 & .370 \\
Linear-by-Linear Association & .155 & 1 & .694 \\
N of Valid Cases & 100 & & \\
\hline
\end{tabular}

a. 13 cells $(65.0 \%)$ have expected count less than 5 . The minimum expected count is .27 . 
INTERPRETATION: The chi-square test has shown that the hypothesis is accepted. Since the significant (0.462) value is less than 0.05 hypothesis is accepted. It also shows that employees are happy with their current position in the organization when it is based on competency mapping.

Interpretation of the current position handled by the employee and promotions in the organization based on skills.

Cross tabulation of response on rating for current position across promotion received based on skill has been tabulated under. The look from the Table makes one to understand $42 \%$ of employees have given the rating $4,9 \%$ of staff have given rating $1,47 \%$ of the employees have given rating 1 for promotions received based on skills, $2 \%$ have given rating 5 .

Table 5. Crosstab

\begin{tabular}{lllllll}
\hline \multicolumn{7}{l}{ Count } \\
\hline & \multicolumn{7}{l}{ promotion received based on skill give ratingTotal } \\
\cline { 2 - 7 } & 1 & 2 & 3 & 4 & 5 \\
& 13 & 4 & 0 & 2 & 0 & 9 \\
& 26 & 4 & 1 & 0 & 0 & 11 \\
to determine rating given for current position 38 & 5 & 1 & 0 & 0 & 14 \\
& 415 & 11 & 10 & 4 & 2 & 42 \\
Total & 515 & 7 & 1 & 1 & 0 & 24 \\
& 47 & 31 & 13 & 7 & 2 & 100 \\
\hline
\end{tabular}

\section{Hypothesis:}

$\mathrm{H}_{3}$ : Opinion on rating on current position is independent of promotions received

Table 6. Chi-Square Tests

\begin{tabular}{cccc}
\hline & Value & df & Asymp. Sig. (2-sided) \\
\hline Pearson Chi-Square & $19.262^{\text {a }}$ & 16 & .255 \\
Likelihood Ratio & 21.606 & 16 & .156 \\
Linear-by-Linear Association & .077 & 1 & .781 \\
N of Valid Cases & 100 & & \\
\hline
\end{tabular}

a. 18 cells $(72.0 \%)$ have expected count less than 5 . The minimum expected count is .18 .

INTERPRETATION: The chi-square test has shown that the hypothesis is accepted. Since the significant (0.255) value is less than 0.05 hypothesis is accepted. It also shows that employees are happy with their current position in the organization and only few employees have agreed that they get promotions based on their skills.

Cross tabulation below makes one to understand $93 \%$ of employees have admitted that training has helped them to perform better $.62 \%$ of the employees have agreed that training has helped them to enhance their skill. $7 \%$ of the employees can't say if the training undergone has helped them to enhance skills or not. 
Table 7. Training Helps to Perform Better = Employee Skill Enhancement

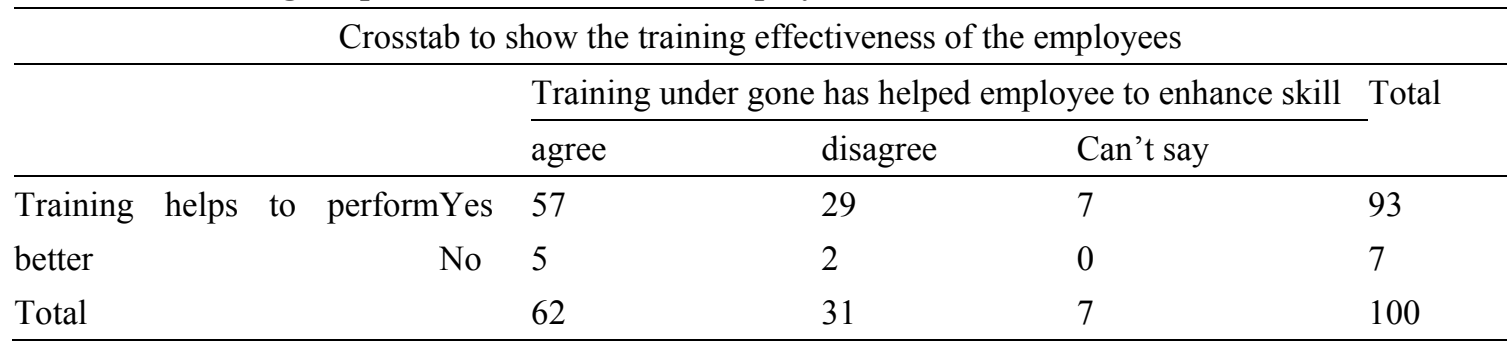

\section{Hypothesis:}

\section{$\mathrm{H}_{4}$ : Opinion on effect of training is independent of enhancement of their skills}

Table 8. Chi-Square Test

\begin{tabular}{cccc}
\hline & Value & df & Asymp. Sig. (2-sided) \\
\hline Pearson Chi-Square & $.649^{\mathrm{a}}$ & 2 & .723 \\
Likelihood Ratio & 1.134 & 2 & .567 \\
Linear-by-Linear Association & .519 & 1 & .471 \\
N of Valid Cases & 100 & & \\
\hline
\end{tabular}

a. 3 cells $(50.0 \%)$ have expected count less than 5 . The minimum expected count is .49 .

INTERPRETATION: The chi-square test has shown that the hypothesis is accepted. Since the significant (0.723) value is greater than 0.05 hypothesis is accepted. From this it can be concluded that training helps to perform better as well as to enhance skill of employees.

\section{Hypothesis:}

$\mathrm{H}_{5}$ : Opinion on effect of training is independent of satisfaction with training provided for improving competency level

Table 9. Chi-Square Tests

\begin{tabular}{|c|c|c|}
\hline & \multicolumn{2}{|c|}{ Value dfAsymp. Sig. (2-sided)Exact Sig. (2-sided)Exact Sig. (1-sided) } \\
\hline Pearson Chi-Square & $2.645^{\mathrm{a}} 1.104$ & \\
\hline Continuity Correction $^{b}$ & 1.3911 .238 & \\
\hline Likelihood Ratio & 4.3981 .036 & \\
\hline Fisher's Exact Test & .185 & .112 \\
\hline \multicolumn{3}{|c|}{ Linear-by-Linear Association2.618 1.106} \\
\hline $\mathrm{N}$ of Valid Cases & 100 & \\
\hline
\end{tabular}

a. 1 cells $(25.0 \%)$ have expected count less than 5 . The minimum expected count is 1.82 .

b. Computed only for a $2 \times 2$ table.

INTERPRETATION: The chi-square test has shown that the hypothesis is accepted. Since the significant (0.104) value is greater than 0.05 hypothesis is accepted. The conclusion can be given from this analysis as training helps to perform better and employees are satisfied with the training for competency level. 


\section{Suggestions}

- Employees in Retail units are fresher's and they require training to enhance skills. Employees have agreed that their roles and responsibilities are clearly defined to them.

- And training is helping them to enhance their skill and contribute towards career development. $47 \%$ of workforce have agreed that organization uses the competency mapping for conducting performance appraisal. $74 \%$ of workforce thinks that training is effective way to increase employee's competency level.

- It is important for Organizations to map competency before allocation of Jobs.

- The chi square analysis shows that employees have agreed that skills and efficiency is important for better performance and competency mapping will help employees to perform better and allocation is done based on the competency mapping.

\section{Conclusion}

By this study we can understand the importance of competency mapping. The work force is the backbone for excellence in performance. The organization has many potential employees who are very skillful. From this study employees deficiencies was found and training was given to improve it. Competency mapping in the organization has helped in increasing performance and potential of employees.

The organization is implemented a new model based on the study conducted which has helped the staff to overcome many difficulties. Proper training is given to employees based on their skills, efficiency and requirement.

It is responsibility of manager to ensure right skillful person is appointed to the right job and to ensure employees are happy with the training and facilities provided.

\section{References}

Janani, \& Gomathic, S. (2015, January). Formulating and Implementing Competency Modelling, Profiling and Mapping. Mediterranean journal of social science, 6(1).

Nagaraju, Y., \& Sathyanarayana, G. V. (n.d.). A study of Employee Competency Mapping Strategies at select organizations of Bangalore. International Journal of Research in Commerce \& Management.

Orooj, S. (2014, November). Competency Mapping: An HR Practice Enhancing the employee Productivity and Growth, 4(11).

Sawant, B. S., \& Avinash, D. (2012). Competency Mapping of the Employees. Global journal of Arts \& Management, 2(2)

Seema, S. (n.d.). The Handbook of Competency Mapping: Understanding, Designing and Implementing Competency Models in Organizations (2nd ed.).

Yuvaraj, R. (2011, August) Competency Mapping-A drive for Indian Industries. International Journal of Scientific \& Engineering Research, 2(8). 